\title{
UJI AKTIVITAS ANTIBAKTERI EKSTRAK ETANOL 70\% DAUN BINAHONG (Anredera cordifolia (Ten.) Steenis) TERHADAP BAKTERI Staphylococcus aureus
}

\author{
I Putu Gede Adi Purwa Hita ${ }^{1}$, Putu Eka Arimbawa ${ }^{2}$, Dhiancinantyan windydaca \\ $\mathbf{B P}^{3}$ \\ ${ }^{1,2,3)}$ Universitas Bali Internasional, Jl. Seroja Denpasar - Bali 80114 \\ e-mail: ${ }^{1)}$ adipurwah.1@gmail.com \\ ${ }^{2)}$ eka_apoteker@yahoo.co.id \\ ${ }^{3)}$ windydacabrataputri@iikmpbali.ac.id
}

\begin{abstract}
ABSTRAK
Pengobatan jerawat dewasa ini didominasi oleh kosmetika khususnya kosmetika sintetis memiliki efek samping yang tinggi, sehingga memerlukan alternatife yaitu pengobatan obat herbal. yang memiliki efek samping lebih sedikit dari obat sintetis. Binahong (Anredera cordifolia (Ten.) Steenis) merupakan salah satu tanaman obat herbal khas Indonesia yang secara empiris digunakan untuk mengobati berbagai macam penyakit. Untuk mengetahui aktivitas antibakteri dari ekstrak etanol 70\% daun binahong (Anredera cordifolia (Ten.) Steenis) terhadap bakteri Staphyloccocus aureus. Pembuatan ekstrak dilakukan dengan metode maserasi menggunakan etanol $70 \%$ dan uji aktivitas antibakteri dilakukan dengan metode difusi cakram yang diukur diameter zona hambatnya. Sebanyak 84,04 gram ekstrak kental daun binahong yang memiliki warna hijau kehitaman, bau khas, dan rasa pahit didapatkan melalui proses ekstraksi. Diameter zona hambat ekstrak yang dihasilkan sebesar 12,97 $\pm 0,54 \mathrm{~mm}$, kontrol positif (kloramfenikol) 30,18 $\pm 0,08$ $\mathrm{mm}$, dan kontrol negatif tidak memberikan zona hambat. Ekstrak etanol $70 \%$ daun binahong (Anredera cordifolia (Ten.) Steenis) memiliki aktivitas antibakteri yang kuat terhadap bakteri Staphylococcus aureus.
\end{abstract}

Kata Kunci: Anredera cordifolia (Ten.) Steenis, ekstrak etanol, antibakteri, Staphylococcus aureus.

\begin{abstract}
Today's acne treatment is dominated by cosmetics, especially synthetic cosmetics, which have high side effects, so it requires an alternative, namely herbal medicinal treatment. which have fewer side effects than synthetic drugs. Binahong (Anredera cordifolia (Ten.) Steenis) is a typical Indonesian herbal medicinal plant which is empirically used to treat various diseases. To determine the antibacterial activity of $70 \%$ ethanol extract of binahong leaves (Anredera cordifolia (Ten.) Steenis) against Staphyloccocus aureus bacteria. The extract was made by maceration method using $70 \%$ ethanol and antibacterial activity test was carried out by using the disc diffusion method which measured the inhibition zone diameter. 84.04 grams of binahong leaf thick extract which has a green-black color, distinctive odor, and a bitter taste was obtained through the extraction process. The resulting extract inhibition zone diameter was $12.97 \pm 0.54 \mathrm{~mm}$, positive control (chloramphenicol) $30.18 \pm 0.08 \mathrm{~mm}$, and negative control did not provide an inhibition zone. The $70 \%$ ethanol extract of binahong leaves (Anredera cordifolia (Ten.) Steenis) has strong antibacterial activity against Staphylococcus aureus bacteria.
\end{abstract}

Keywords: Anredera cordifolia (Ten.) Steenis, ethanol extract, antibacterial, Staphylococcus aureus. 


\section{PENDAHULUAN}

Jerawat yang sering timbul pada muka, bahu, dada, punggung, leher, dan lengan merupakan kondisi sangat umum dengan melibatkan gangguan dari unit pilosebasea yang mempengaruhi jutaan orang di seluruh dunia (Wasitaatmadja, 2011). Pengobatan jerawat dewasa ini didominasi oleh kosmetika khususnya kosmetika sintetis memiliki efek samping yang tinggi salah satunya ditunjukkan dari hasil monitoring efek samping kosmetika yang tertinggi memiliki efek samping yaitu terjadi pada sediaan krim sintesis. Senyawa-senyawa yang bertanggung jawab dalam hal ini antara lain adalah zat kimia berbahaya seperti merkuri (Hg), pewarna sintetis (K10 dan K3), hidrokinon, dan asam retinoat (Tringani et al., 2011). Oleh karena itu perlu adanya formulasi dari bahan alternatif lain untuk mengurangi efek samping yang tidak diinginkan.

Salah satu alternatif yaitu penggunaan obat herbal hal ini dikarenakan obat herbal memiliki efek samping yang lebih sedikit dari obat sintetis (Hanutami dan Arif, 2017). Obat herbal merupakan tanaman yang memiliki khasiat obat dan digunakan sebagai obat dalam penyembuhan maupun pencegahan penyakit. Salah satu contoh obat herbal yaitu daun binahong (Anredera cordifolia (Ten.) Steenis). Daun binahong merupakan salah satu tanaman khas Indonesia yang secara empiris digunakan untuk mengobati berbagai macam penyakit, antara lain untuk menyembuhkan luka luar akibat goresan senjata tajam, meningkatkan stamina tubuh, mengobati sakit maag, wasir, menyembuhkan memar, rematik (Samirana, 2016). Khasiat secara empiris dari daun binahong tersebut dapat menjadi dasar pengobatan alternative untuk jerawat dan harus dibuktikan secara ilmiah, salah satunya dengan menguji aktivitas antibakteri dari ekstrak etanol 70\% daun binahong terhadap bakteri Staphyloccocus aureus sebagai salah satu penyebab jerawat.

\section{METODOLOGI PENELITIAN}

\section{Bahan}

Simplisia daun binahong (Anredera cordifolia (Ten.) Steenis), aquadestilata, etanol 70\% (PT. Brataco), Nutrient Agar (Oxoid), larutan saline ( $\mathrm{NaCl}$ ) steril, bakteri Staphylococcus aureus, cakram disk, dan kloramfenikol.

\footnotetext{
Alat

Alat maserasi, alat-alat gelas (Pyrex), rotary evaporator (IKA), corong Buchner (Merk), timbangan analitik (Acic AD- 2100H), pinset, dan autoklaf (GEA).
} 


\section{Pembuatan Ekstrak}

Simplisia daun binahong (Anredera cordifolia (Ten.) Steenis) yang diperoleh dari daerah Bangli, Bali. 1000 g simplisia kemudian diekstraksi menggunakan metode maserasi dengan etanol $70 \%$ sebanyak $5 \mathrm{~L}$ di dalam sebuah maserator selama 3 hari dengan perlakuan sekali dikocok dan dengan melakukan dua kali remaserasi masing-masing dengan etanol 70\% sebanyak 2,5 L. Kemudian hasil maserasi disaring menggunakan corong Buchner dan filtrat dipekatkan dengan rotary evaporator pada suhu $50^{\circ} \mathrm{C}$.

\section{Sterilisasi alat dan bahan}

Alat dan bahan yang sudah disediakan dibungkus dengan aluminium foil agar tahan panas. Isi Autoclave dengan air secukupnya. Kemudian masukan alat dan bahan yang sudah dibungkus dengan aluminium foil kedalam autoclave yang berada di Laboratorium Universitas Bali Internasional dengan suhu $120^{\circ} \mathrm{C}$ selama 15 menit.

\section{Penyiapan Media Nutrient Agar (NA)}

7,25 gram Nutrient Agar (NA) dimasukkan ke dalam labu erlenmeyer lalu ditambahkan dengan $250 \mathrm{~mL}$ aquades dan dipanaskan dengan menggunakan hotplate selama \pm 10 menit hingga Nutrient Agar (NA) larut. Media yang telah homogen disterilisasi di dalam autoklaf selama 15 menit pada suhu $121^{\circ} \mathrm{C}$. Setelah itu media ditunggu hingga agak dingin sekitar suhu $40-45^{\circ} \mathrm{C}$ dan tuangkan ke cawan petri sebanyak $20 \mathrm{~mL}$. Media Nutrient Agar (NA) yang telah dituang ke dalam cawan petri dibiarkan hingga memadat.

\section{Pembuatan Media Bakteri Staphylococcus aureus}

Kultur murni bakteri Staphylococcus aureus dibuat suspensi, dengan 1 ose kultur murni bakteri disuspensikan dalam larutan saline $(\mathrm{NaCl})$ steril sebanyak $10 \mathrm{~mL}$, larutan saline steril digunakan untuk pembuatan suspensi dengan tujuan agar bakteri uji tidak mengalami lisis, dihomogenkan lalu kekeruhan suspensi dibandingkan dengan standard larutan Mc. Farland 0,5 untuk mendapatkan suspensi sesuai standard, dengan jumlah pertumbuhan $10^{8} \mathrm{CFU}$. Kemudian dilanjutkan dengan tahap inokulasi bakteri dengan cara bakteri uji diambil dengan jarum ose steril sebanyak satu ose, kemudian ditanam di media Nutrient Agar (NA) secara aseptik menggunakan metode spread plate atau metode sebar.

\section{Penyiapan sampel}

Pembuatan Cakram/Disc dilakukan dengan menggunakan kertas cakram steril yang kemudian dijenuhkan dengan ekstrak untuk sampel uji, larutan kontrol positif yaitu 
kloramfenikol, dan aquadest sebagai kontrol negatif. Sampel uji dibuat dengan cara melarutkan 4 gram ekstrak daun binahong (Anredera cordifolia (Ten.) Steenis) dalam 5 $\mathrm{mL}$ etanol.

\section{Uji Aktivitas Antibakteri}

Pengujian aktivitas antibakteri ekstrak daun binahong menggunakan metode difusi agar dengan Metode cakram difusi agar (Agar Disk Diffusion Test). Cakram yang telah mengandung sampel uji, kontrol positif, dan control negatif diletakkan di permukaan pelat agar yang mengandung organisme yang diuji. Kemudian diinkubasi selama 2 x 24 jam pada suhu $37^{\circ} \mathrm{C}$. Aktivitas antibakteri dapat terlihat dengan adanya zona hambat dan dilakukan replikasi sebanyak empat kali. Zona hambatan tampak sebagai area jernih atau bersih yang mengelilingi cakram tempat zat dengan aktivitas antimikroba terdifusi.

\section{HASIL DAN PEMBAHASAN}

Tabel 1. Hasil Diameter Zona Hambat

\begin{tabular}{ccccccc}
\hline & $\begin{array}{c}\text { Replikasi } \\
1(\mathrm{~mm})\end{array}$ & $\begin{array}{c}\text { Replikasi } \\
2(\mathrm{~mm})\end{array}$ & $\begin{array}{c}\text { Replikasi } \\
3(\mathrm{~mm})\end{array}$ & $\begin{array}{c}\text { Replikasi } \\
4(\mathrm{~mm})\end{array}$ & $\begin{array}{c}\text { Rata-Rata } \\
(\mathrm{mm})\end{array}$ & $\begin{array}{c}\text { Standar } \\
\text { Deviasi }\end{array}$ \\
\hline Kontrol Positif & 30,18 & 30,1 & 30,13 & 30,3 & 30,18 & 0,08 \\
$\begin{array}{c}\text { Kontrol Negatif } \\
\text { Sampel Uji (Ekstrak } \\
\text { Daun Binahong) }\end{array}$ & 0 & 0 & 0 & 0 & 0 & 0 \\
\hline
\end{tabular}

Tabel 2. Kriteria Kekuatan Aktivitas Antibakteri (Hapsari, 2015)

\begin{tabular}{cc}
\hline Diameter Zona Hambat & $\begin{array}{c}\text { Kekuatan Daya } \\
\text { Hambat }\end{array}$ \\
\hline$>20 \mathrm{~mm}$ & Sangat Kuat \\
$10-20 \mathrm{~mm}$ & Kuat \\
$5-10 \mathrm{~mm}$ & Sedang \\
$0-5 \mathrm{~mm}$ & Lemah \\
\hline
\end{tabular}

Sebanyak 84,04 gram ekstrak kental daun binahong (Anredera cordifolia (Ten.) Steenis) didapatkan melalui proses ekstraksi menggunakan metode maserasi dengan karakteristik bentuk kental, warna hijau kehitaman, bau khas, dan rasa yang pahit. Tabel 1. menunjukkan ekstrak etanol 70\% daun binahong memiliki aktivitas antibakteri terhadap pertumbuhan bakteri Staphylococcus aureus dengan diameter zona hambat yang dihasilkan sebesar 12,97 $\pm 0,54 \mathrm{~mm}$ berbanding terbalik dengan control negatif yang tidak menghasilkan diameter zona hambat. Apabila dinilai dari Tabel 2. ekstrak etanol $70 \%$ daun binahong memiliki aktivitas antibakteri yang kuat dan kontrol positif 
(kloramfenikol) memiliki aktivitas antibakteri yang sangat kuat. Aktivitas antibakteri ini disebabkan oleh kandungan metabolit sekunder yang terkandung dalam ekstrak.

Metabolit sekunder tumbuhan merupakan senyawa metabolit yang dihasilkan oleh tumbuhan dalam proses adaptasinya dengan lingkungan. Terdapat beberapa senyawa metabolit sekunder yang berperan dalam menghambat pertumbuhan mikroorganisme patogen. Beberapa contohnya adalah fenol, flavonoid, alkaloid, tannin, saponin, dan terpenoid (Hanphakphoom et al., 2016). Mekanisme kerja flavonoid sebagai antibakteri Terdapat beberapa mekanisme kerja flavonoid sebagai antibakteri yaitu : menghambat sintesis asam nukleat, menghambat fungsi membran sel bakteri, menghambat metabolisme energi dalam sel bakteri, dan menghambat penggunaan oksigen oleh bakteri (Liantari, 2014; Riwayati, 2012). Tanin merupakan senyawa metabolit sekunder yang dapat menghambat enzim reverse transkriptase dan DNA topoisomerase sehingga sel bakteri tidak dapat terbentuk (Mukhlisoh, 2010; Savitri, 2014). Alkaloid, saponin dan terpenoid memiliki aktivitas sebagai antibakteri dengan mekanisme menyebabkan kebocoran protein, menghambat produksi komponen dinding sel bakteri seperti peptidoglikan, dan enzim dari dalam sel dan merusak porin sehingga membrane sel bakteri tidak berfungsi (Safangat et al., 2014; Amirah et al., 2019; Tim et al., 2014).

\section{SIMPULAN}

Ekstrak etanol 70\% daun binahong (Anredera cordifolia (Ten.) Steenis) memiliki aktivitas antibakteri yang kuat terhadap bakteri Staphylococcus aureus dengan nilai diameter zona hambat $12,97 \pm 0,54 \mathrm{~mm}$. Data awal aktivitas antibakteri ekstrak etanol $70 \%$ daun binahong dapat menjadi acuan untuk penelitian lebih lanjut seperti standarisasi ekstrak, skrining fitokimia, dan pengujian aktivitas antibakteri dengan golongan bakteri yang berbeda-beda sehingga nantinya dapat dihasilkan produk komersil berbahan dasar herbal.

\section{DAFTAR PUSTAKA}

Amirah, N. M., Shun-Kai Y., Chew-Li M., Adelene A. S., Chou-Min C., Chun-Wie C., Aisha A., Swee-Hua E. L., dan Kok-Song L. 2019. Terpene Derivatives as a Potential Agent against Antimicrobial Resistance (AMR) Pathogens. Molecules, 24,2631: 1-21.

Hanphakphoom, S., Thophon, S., Waranusantigul, P., Kangwanrangsan, N., dan Krajangsan, S. 2016. Antimicrobial Activity of Chromolaena odorataExtracts Agains Bacterial Human Skin Infections. Modern Applied Science, Vol. 10 No. 2 :159-171. 
Hanutami, B. N. P. dan Arif B. 2017. Review Artikel : Penggunaan Teknologi Nano Pada Formulasi Obat Herbal. Farmaka, Suplemen Volume 15 No. 2 : 29-31.

Liantari, Diah Septia. 2014. Effect of Wuluh Starfruit Leaf Extract for Streptococcus Mutans Growth. J Majority. Vol 3(2) : 27-33.

Mukhlisoh, W.. 2010. Pengaruh Ekstrak Tunggal dan Gabungan Daun Belimbing Wuluh (Averrhoa bilimbi Linn) Terhadap Aktivitas Anti Bakteri Secara In Vitro. Skripsi. Universitas Islam Negri Maulana Malik Ibrahim.

Riwayati, Dina. 2012. Aktivitas Antibakteri Ekstrak Etanol Daun Belimbing Wuluh (Averrhoa bilimbi L.) Terhadap Escherichia Coli Dan Bacillus Sp.. Skripsi. Surakarta : Universitas Muhammadiyah Surakarta.

Safangat, A., Sarwiyono, dan P. Surjowardojo. 2014. Pengaruh penggunaan jus daun kelor (Moringa oleifera) untuk teat dipping terhadap kejadian mastitis sub klinis sapi perah FH laktasi. Skripsi. Malang : Fakultas Peternakan Universitas Brawijaya.

Samirana, P. O., Swastini D. A., Subratha, I D. G. P. Y., dan Ariadi, K. A. 2016. Uji Aktivitas Penyembuhan Luka Ekstrak Etanol Daun Binahong (Anredera scandens (L.) Moq.) pada Tikus Jantan Galur Wistar. Jurnal Farmasi Udayana, Vol. 5 No. $2: 19-23$.

Savitri, Ni Putu Iga. 2014. Efektivitas Antibakteri Ekstrak Daun Belimbing Wuluh (Averrhoa bilimbi L.) terhadap Bakteri MIX Saluran Akar Gigi. Skripsi. Denpasar: Universitas Mahasaraswati.

Tim, T. P. C., Benjamart C., Andrew J.L. 2014. Alkaloids: An Overview Of Their Antibacterial, Antibiotic-enhancing, And Antivirulence Activities. International Journal of Antimicrobial Agents : 1-14.

Tringani, D., Kristiana E., dan Retna S. W. 2011. Persepsi Remaja Putri di Kota Ambon Tentang Risiko Terpapar Kosmetik Berbahaya dan Perilakunya dalam Memilih dan Menggunakan Kosmetik. Berita Kedokteran Masyarakat, Vol. 27, No. 1 : 19.

Wasitaatmadja, S. M. 2011. Ilmu penyakit kulit dan kelamin. Edisi 6. Jakarta: Balai Penerbit FKUI. 